Natalia Miłostan

Uniwersytet Wrocławski

\title{
POLITYKA ZRÓWNOWAŻONEGO ROZWOJU W ZAMÓWIENIACH PUBLICZNYCH
}

\section{Wprowadzenie}

Zamówienia publiczne są prawnym sposobem kontroli wydatkowania środków publicznych przez podmioty zarządzające tymi środkami, corocznie wydaje się wiele miliardów euro na przedsięwzięcia realizowane w drodze zamówień publicznych. Środki publiczne wydatkowane przez podmioty publiczne stanowią znaczącą część dochodu PKB w Polsce. ${ }^{1}$ Za pomocą środków publicznych można realizować różne cele, jak również integrować różne działania, aby osiągnąć wspólny cel. Ze względu na znaczącą rolę środków publicznych w gospodarce system zamówień publicznych został uznany za jeden z elementów polityki ochrony środowiska Unii, jak i w Polsce. W związku z czym w ramach tworzenia ram prawnych zamówień publicznych wprowadzono w nim możliwość realizacji zamówienia, którego celem będzie dostawa, usługa lub robota budowlana wspierająca zrównoważony rozwój środowiska, jak i jego ochronę. Przedstawiciele Komisji Europejskiej szacują, że wdrożenie procedur ochrony środowiska do praktyki realizacji zamówień publicznych może się przyczynić do znacznego obniżenia zużycia energii, kosztów eksploatacji urządzeń, technologii i wyposażenia oraz na przestrzeni całego okresu ich eksploatacji do uzyskania przez wdrażające je podmioty znaczących korzyści finansowych i środowiskowych.

Celem artykułu jest omówienie elementów polityki zrównoważonego rozwoju stosowanych bądź mogących być stosowane w zamówieniach publicznych. Szczegółowo zostały przeanalizowane tzw. zielone zamówienia publiczne jako praktyczny instrument ochrony środowiska i polityki ekologicznej, który może być stosowany

1 Jak wynika z rocznych sprawozdań o udzielonych zamówieniach przekazanych przez zamawiających, wartość rynku zamówień publicznych w roku 2011 można oszacować na kwotę ok. 144,1 mld zł. Oszacowana wartość rynku zamówień publicznych stanowiła ponadto ok. 9,5\% produktu krajowego brutto (PKB) z roku 2011, zob. Sprawozdanie o funkcjonowaniu systemu zamówień publicznych w 2011 roku, Warszawa 2012. 
przez zamawiających. W artykule zostaną omówione możliwości wykorzystania kryteriów środowiskowych na różnych etapach postępowania o udzielenie zamówienia publicznego, których skutkiem będzie dążenie do realizacji zasad zrównoważonego rozwoju.

\section{Zrównoważony rozwój jako zasada ustroju państwa}

Pojęcie zrównoważonego rozwoju zostało po raz pierwszy sformułowane na III Sesji Zarządzającej Programu Ochrony Środowiska Narodów Zjednoczonych w 1975 r., jednak dopiero w latach 80. XX wieku zaczęto dostrzegać jego istotną rolę. Aktualny kształt koncepcji zrównoważonego rozwoju wynika z raportu „Our Common Future”, ${ }^{2}$ w którym określono, iż: „zrównoważony rozwój to rozwój, który zaspokaja potrzeby obecne, nie pozbawiając przyszłych pokoleń możliwości zaspokajania ich potrzeb". ${ }^{3}$ Taka koncepcja stanowiła fundament do kształtowania rozumienia pojęcia zrównowazonego rozwoju na gruncie prawa wspólnotowego. Na gruncie polityki UE wdrożenie zasad zrównoważonego rozwoju stało się jednym z głównych zadań stojących przed krajami członkowskimi w wyniku podpisania w 1997 r. Traktatu Amsterdamskiego. ${ }^{4}$ Własną Strategię Zrównoważonego Rozwoju Unia Europejska posiada od 2001 r., kiedy to w Göteborgu został przyjęty dokument A Sustainable Europe for a Better World: A European Union Strategy for Sustainable Development. ${ }^{5} \mathrm{~W}$ ramach tego aktu uszczegółowiono, iż zrównoważony rozwój jest głównym celem wszystkich obszarów polityki Wspólnoty Europejskiej, a jego celem jest ciągła poprawa jakości życia zarówno obecnych, jak i przyszłych pokoleń, a także zapewnienie możliwości utrzymania pełnej różnorodności form życia na Ziemi. ${ }^{6}$

Na gruncie prawa polskiego zasada zrównoważonego rozwoju została uznana jako podstawowa zasada polityki państwa i umieszczona w art. 5 Konstytucji, w myśl którego: „Rzeczpospolita Polska zapewnia ochronę środowiska, kierując się zasadą zrównoważonego rozwoju". ${ }^{7}$ Realizacja tej zasad należy do zadań wszystkich władz państwa, które posiłkują się dodatkowo definicją zrównoważonego rozwoju wynikającą z art. 3 pkt 50 ustawy Prawo ochrony środowiska. ${ }^{8}$ Nakazuje on, aby

2 A. Pawłowski, Rewolucja rozwoju zrównoważonego, „Problemy Ekorozwoju” 2009, vol. 4, no 1, s. 65-76, zob. szerzej także, WCED Bruntland Commission: Our Common Future, Oxford 1987, s. 41-42.

3 M. Górski, M. Pchałek, W. Radecki, J. Jerzmański. M. Bar, S. Urban, J. Jendrośka, Prawo ochrony środowiska. Komentarz, Warszawa 2011, s. 125.

$4 \quad$ Traktat z Amsterdamu zmieniający Traktat o Unii Europejskiej, Traktaty ustanawiające Wspólnoty Europejskie oraz niektóre związane z nimi akty, (Dz.U. z 2004 r. Nr 90, poz. 864/30 ze zm.). 5 A Sustainable Europe for a Better World: A European Union Strategy for Sustainable Development, more on its nie polityk, Warsaw 2004, s. 11-12.

6 M. Górski, M. Pchałek, W. Radecki, J. Jerzmański, M. Bar, S. Urban, J. Jendrośka, Prawo ochrony środowiska. Komentarz, Kraków 2011, s. 126

$7 \quad$ Konstytucja RP, Dz.U. z 16 lipca 1997 r. Nr 78, poz. 483, ze zm.

8 Ustawa z dnia 27 kwietnia 2001 r. - Prawo ochrony środowiska (Dz.U. z 2001 r. Nr 62, poz. 627 z późn. zm.). 
koncepcja zrównoważonego rozwoju zawierała w sobie integrowanie działań politycznych, gospodarczych i społecznych z zachowaniem równowagi przyrodniczej oraz trwałości podstawowych procesów przyrodniczych. Wynikiem tak szerokiego ujęcia zrównoważonego rozwoju jest Krajowy Plan Działań w zakresie zrównoważonych zamówień publicznych, ${ }^{9}$ który realizuje rekomendacje zawarte w dokumentach międzynarodowych zgodnie z zapisami Ustawy o zasadach prowadzenia polityki rozwoju ${ }^{10}$ i jest również spójny ze Strategią Rozwoju Kraju 2007-2015. Celem Krajowego Planu Działań w zakresie zrównoważonych zamówień publicznych jest promocja rozwiązań przewidzianych w procedurach przetargowych, które mogą pozytywnie wpłynąć na rozwój ekoinnowacji oraz postaw prospołecznych. Bowiem należy się tutaj przychylić do stwierdzenia Z. Sadowskiego, który określa zrównoważony rozwój jako zrównoważony typ rozwoju, w którym zagrażające w skali światowej warunkom życia następnych pokoleń, narastające ekologicznie koszty rozwoju ulegają eliminacji, dzięki świadomemu nakierowaniu działań gospodarczych ludzi na ochronę środowiska naturalnego. ${ }^{11} \mathrm{~W}$ doktrynie zrównoważonego rozwoju podkreśla się, że najważniejszy jest rozwój społeczny, gospodarczy i ekonomiczny. Definicja legalna zrównoważonego rozwoju została zawarta w art. 3 pkt 50 ustawy z dnia 27 kwietnia 2001 r. Prawo ochrony środowiska. Przez rozwój zrównoważony należy rozumieć taki rozwój społeczno-gospodarczy, w którym następuje proces integrowania działań politycznych, gospodarczych i społecznych z zachowaniem równowagi przyrodniczej oraz trwałości podstawowych procesów przyrodniczych, w celu zagwarantowania możliwości zaspokajania podstawowych potrzeb poszczególnych społeczności lub obywateli zarówno współczesnego pokolenia, jak i przyszłych pokoleń. Wymaga podkreślenia, że w Polsce zasada zrównoważonego rozwoju ma podstawy konstytucyjne, zatem jej charakter jest ustrojowy i zgodnie z nią działać mają wszystkie podmioty administracji publicznej. ${ }^{12}$

\section{Nowe podejście do zamówień publicznych a zrównoważony rozwój}

Koncepcja zrównoważonego rozwoju przez lata nie była dostrzegana w prawodawstwie dotyczącym zamówień publicznych, zarówno w zakresie norm prawa unijnego, jak również w przepisach krajowych. Sytuacja uległa zmianie wraz ze

9 Krajowy Plan Działań w zakresie zrównoważonych zamówień publicznych, Urząd Zamówień Publicznych, Warszawa 2010.

10 Ustawa z dnia 6 grudnia 2006 r. o zasadach prowadzenia polityki rozwoju, (Dz.U. z 2006 r. Nr 227, poz. 1658 z późn. zm.).

11 Z. Sadowski, Dezyderat trwałego rozwoju i warunki jego spełnienia. (Tezy), (w:) A. Pawłowski (red.), Filozoficzne i społeczne uwarunkowania zrównoważonego rozwoju, „Monografie Komitet Inżynierii Środowiska PAN” 2003, vol. 16, s. 14.

12 H. Lisicka, Polityka ochrony środowiska w polityce państwa, (w:) A. Papuziński (red.), Polityka ekologiczna III Rzeczypospolitej, Bydgoszcz 2000, s. 32-35; Z. Bukowski, Lokalna agenda 21, „Samorząd Terytorialny” 2003, nr 3, s. 62 . 
zmianami w sytuacji społeczno-ekonomicznej na świecie oraz pojawieniem się idei zrównoważonego rozwoju, której realizacja została pod koniec lat 90 . XX w. uznana za nadrzędny cel UE. Od roku 2000 zaczęto w politykach UE realizować założenia związane z rozwojem Unii Europejskiej, w ramach której miała się ona stać najbardziej konkurencyjną i dynamiczną oraz opartą na wiedzy gospodarką na świecie, mogącą zapewnić zrównoważony wzrost gospodarczy, z większą liczbą i lepszymi miejscami pracy oraz większą spójnością społeczną ${ }^{13}$ Strategia Lizbońska zapoczątkowała w rozwoju procedur wspierających działania proekologiczne w zakresie formułowania kierunków zmian dotychczasowych działań państw na kontynencie europejski. W strategii zrównoważonego rozwoju wskazano cztery obszary priorytetowe, które wymagały natychmiastowych działań: zmiana klimatu, przyroda i bioróżnorodność, zarządzanie zasobami oraz środowisko i zdrowie. Zmiana dotychczasowych założeń dotyczących kierunku rozwoju Unii Europejskiej wpłynęła także na zmiany w systemie zamówień publicznych, gdzie w celu promowania zrównoważonego rozwoju i wpływania na ochronę środowiska wprowadzono znaczące nowelizacje obu dyrektyw, ${ }^{14}$ które dopuściły możliwość brania pod uwagę aspektów ochrony środowiska przy tworzeniu specyfikacji istotnych warunków zamówienia i specyfikacji technicznych oraz kryteriów oceny ofert.

Najważniejszym przejawem uwzględnienia założeń zrównoważonego rozwoju w zakresie wszystkie elementów procedury udzielenia zamówienia publicznego było włączenie aspektów środowiskowych do procedur, które zostały nazwane „zielonymi” zamówieniami publicznymi. „Zielone” zamówienia publiczne na gruncie europejskim są traktowane jako wspólna inicjatywa państw zaangażowanych w politykę ochrony środowiska, które to realizowały projekty wpływające pozytywnie na środowisko. Definicję ,zielonych” zamówień publicznych odnajdujemy w Komunikacie Komisji Europejskiej, ${ }^{15}$ gdzie pod tym pojęciem rozumiana jest polityka, w ramach której podmioty publiczne włączają kryteria i/lub wymagania ekologiczne do procedur udzielania zamówień publicznych i poszukują rozwiązań ograniczających negatywny wpływ produktów/usług na środowisko oraz uwzględniających cały cykl życia produktów, a poprzez to wpływają na rozwój i upowszechnienie technologii środowiskowych. Szczegółowe zalecenia dotyczące uwzględniania aspektów środowiskowych zawarte są w dyrektywie 2004/18/WE w sprawie koordynacji procedur udzielania zamówień publicznych na roboty budowlane, dostawy i usługi. Podobne zasady zostały wprowadzone w dyrektywie 2004/17/WE koordynującej procedury udzielania zamówień przez podmioty działające w sektorach gospodarki

13 J. Radło, Wyzwanie konkurencyjności. Strategia Lizbońska w poszerzonej Unii Europejskiej, Warszawa 2003, s. 24.

14 Zob. szerz.: Dyrektywa 2004/18 Parlamentu Europejskiego oraz Rady z dnia 31 marca 2004 r. w sprawie koordynacji procedur udzielania zamówień publicznych na roboty budowlane, dostawy i usługi oraz Dyrektywa 2004/17 Parlamentu Europejskiego oraz Rady z dnia 31 marca 2004 r. w sprawie koordynacji procedur udzielania zamówień w sektorach gospodarki wodnej, energetyki, transportu i usług pocztowych. Komunikat KE Zamówienia publiczne na rzecz poprawy stanu środowiska COM (2008)400. 
wodnej, energetyki, transportu i usług pocztowych. W preambułach do dyrektyw stwierdza się, iż „podmioty (instytucje) zamawiające, które chcąc zdefiniować wymagania dotyczące ochrony środowiska $w$ ramach specyfikacji technicznych danego zamówienia mogą określić aspekty środowiskowe, obejmujące na przykład metody produkcji i/lub specyficzny wpływ grupy produktów lub usług na środowisko". Zgodnie z dyrektywą 2004/18/WE stosowanie kryteriów środowiskowych w procedurach przetargowych ma na celu promowanie zrównoważonego rozwoju, zapewniając jednocześnie możliwość uzyskania przez instytucje zamawiające zamówienia o najkorzystniejszej relacji jakości do ceny. ${ }^{16}$ Dyrektywa przewiduje możliwość uwzględniania kryteriów środowiskowych $\mathrm{w}$ poszczególnych fazach procedury udzielania zamówień publicznych, tj. opisie przedmiotu zamówienia, kwalifikacji wykonawców, kryteriach udzielenia zamówienia i warunkach realizacji zamówienia. Tworzenie „, zielonego” zamówienia publicznego jako przedmiotu realizacji wspólnej polityki w ramach zamówień publicznych może przybierać różne formy. Niezależnie bowiem, w którym etapie postępowania włączymy aspekty środowiskowe, gdy będą one wynosiły $15 \%,{ }^{17}$ wówczas będziemy mówili o ,zielonym” zamówieniu publicznym. Potencjał zamówień publicznych nakierowanych na realizację celów środowiskowych realizowany na gruncie dyrektywy sektorowej i klasycznej, uszczegółowiono i dokładnie wskazano w komunikacie Komisji Europejskiej pod tytułem Zamówienia publiczne na rzecz poprawy stanu środowiska naturalnego. ${ }^{18}$ Oprócz tego komunikatu, w lutym 2004 r. Komisja Europejska przyjęła komunikat w sprawie włączenia aspektów ekologicznych do normalizacji europejskiej. ${ }^{19}$ Umożliwia to organom zawierającym umowy zwracanie się o produkty wytwarzane metodami przyjaznymi dla środowiska naturalnego lub przyznawanie dodatkowych punktów produktom wytwarzanym takimi metodami.

Realizacja zrównoważonych zamówień publicznych wzmacnia i uzasadnia działania regulacyjne administracji oraz przyczynia się do kształtowania pozytywnego wizerunku podmiotu realizującego zakupy. Ze względu na interes społeczny, w tym potrzebę poprawy jakości życia oraz stanu środowiska pożądane i celowe jest, aby w zamówieniach publicznych aspekty środowiskowe i społeczne były uwzględniane w jak najszerszym zakresie. Działania administracji publicznej powinny dotyczyć w szczególności wspierania rozwiązań energo-, wodo- i materiałooszczędnych,

16 Zamówienia publiczne na rzecz poprawy stanu środowiska, Komunikat Komisji Europejskiej COM(2008). 400 z dnia 16 lipca $2008 \mathrm{r}$.

17 Już określenie kryteriów środowiskowych na poziomie $10 \%$ pozwala uznać zamówienie publiczne za „zielone”. Jednakże należy pamiętać, iż zgodnie z Orzeczeniem Trybunału Sprawiedliwości w sprawie Wienstrom, Rs. Orzeczenie C-448/01, Sprawozdania Europejskiego Trybunału Sprawiedliwości z dnia 4 grudnia 2003 r., poziom kryteriów środowiskowych nie powinien przekraczać $45 \%$.

18 Komunikat KE Zamówienia publiczne na rzecz poprawy stanu środowiska COM (2008)400, s. 17.

19 Ibidem, s. 19. 
które mogą być atrakcyjne dla zamawiających z uwagi na korzyści ekonomiczne w krótko- i w długookresowej perspektywie. ${ }^{20}$

\section{Przykłady polityki zrównoważonego rozwoju w opisie przedmiotu zamówienia}

Dyrektywy $2004 / 17^{21}$ i $2004 / 18^{22}$ zezwalają także na to, by kryteria środowiskowe, poza opisem przedmiotu zamówienia oraz kryteriami oceny ofert, były stosowane do oceny, czy dany wykonawca spełnia warunki udziału w postępowaniu. Ponadto pewne rozwiązania przyjazne środowisku mogą być zawarte $\mathrm{w}$ umowach podpisywanych $\mathrm{w}$ wyniku przeprowadzenia procedury zamówienia publicznego, której wzór musi być dostępny dla wykonawców wraz z SIWZ. Te klauzule mogą być zawarte chociażby w określeniu sposobu dostarczenia towarów czy ich transportu. Wybór najwłaściwszego sposobu realizacji „zielonych” zamówień publicznych zależy od samego zamawiającego i jego specyficznych potrzeb w tym zakresie, a także od brzmienia odpowiednich przepisów prawa. Wszędzie tam, gdzie zamawiający ma możliwość wyboru dodatkowych oraz racjonalnych elementów opisu przedmiotu zamówienia w ramach realizacji założeń zrównoważonego rozwoju powinien uwzględniać wymagania ochrony środowiska. Nie zostało to bezpośrednio wyrażone w zapisach p.z.p., które w art. 7 ust. 1 formułuje zasadę prymatu uczciwej konkurencji i równego traktowania. ${ }^{23}$ Pomimo braku bezpośredniego wyrażania zasady ochrony środowiska jako zasady obowiązującej zamawiającego podczas opisu przedmiotu zamówienia ma on możliwość swobodnego kształtowania opisu przedmiotu zamówienia. Zarówno opis szczegółowy wyrażony za pomocą dokładnych norm technicznych, jak również opis funkcjonalny dają zamawiającemu możliwość opisywania przedmiotu zamówienia z uwzględnieniem kryteriów środowiskowych. Przykładem podstawowego kryterium, które może uwzględnić zamawiający, jest posiadanie wdrożonego systemu SZJ [Systemu Zarządzania Jakością] lub ISO, które nie może być warunkiem podmiotowym, czyli konstruowanym na podstawie art. 22 ust. 1 ustawy p.z.p. Jest to zawsze warunek przedmiotowy, ponieważ SZJ nie odnosi się do wykonawcy, ale do szeroko pojętego wyrobu. ${ }^{24}$ Pomocnym elementem

20 Krajowy Plan Działań w zakresie zrównoważonych zamówień publicznych, Urząd Zamówień Publicznych, Warszawa 2010, s. 4.

21 Dyrektywa 2004/17/WE Parlamentu Europejskiego i Rady z dnia 31 marca 2004 r. w sprawie koordynacji procedur udzielania zamówień przez podmioty działające w sektorach gospodarki wodnej, energetyki, transportu i usług pocztowych (Dz. Urz. UE L 134 z dnia 30.04.2004 r.).

22 Dyrektywy 2004/17 Parlamentu Europejskiego oraz Rady z dnia 31 marca 2004 r. w sprawie koordynacji procedur udzielania zamówień w sektorach gospodarki wodnej, energetyki, transportu i usług pocztowych (Dz. Urz. UE L 134 z dnia 30.04.2004 r.).

23 Art. 7 ust. 1 ustawy p.z.p.; Zamawiający przygotowuje i przeprowadza postępowania o udzielenie zamówienia w sposób zapewniający zachowanie uczciwej konkurencji oraz równe traktowanie wykonawców", (Dz.U. z 2010 r. Nr 113, poz. 759 t.j.), zwana dalej p.z.p.

24 E. Grabowska-Szweicer, Normy ISO i systemy zarządzania w postępowaniu o udzielenie zamówienia publicznego, „Zamówienia Publiczne. Doradca” 2008, nr 12, s. 64. 
w zakresie opisywania przedmiotu zamówienia z użyciem kryteriów środowiskowych jest cykl życia produktu ${ }^{25}$ oraz szczegółowa analiza produktu z uwzględnieniem kart produktu. ${ }^{26} \mathrm{~W}$ przypadku gdy zamawiający stosują opis funkcjonalny przedmiotu zamówienia, określać w nim mogą sposób oddziaływania na środowisko w kategoriach charakterystyki i wymagań. Jednocześnie do opisu przedmiotu zamówienia mogą wykorzystać szczegółowe specyfikacje określone w ekoetykietach europejskich lub (wielo-) narodowych albo w jakichkolwiek innych ekoetykietach. Jednakże stosowanie opisów przedmiotu zamówienia z wykorzystaniem gotowych ekoetykiet odbywa się pod pewnymi warunkami. Przede wszystkim przedmiotowe etykiety bądź specyfikacje ekologiczne umożliwiają odpowiednie zdefiniowanie dostaw lub usług będących przedmiotem zamówienia. Wymagania dotyczące etykiet określa się na podstawie informacji naukowych, a ekoetykiety przyjmowane są zgodnie z procedurą, w której mogą brać udział wszystkie zainteresowane strony, takie jak instytucje rządowe, konsumenci, producenci, dystrybutorzy oraz organizacje związane z ochroną środowiska, oraz są one dostępne dla wszystkich zainteresowanych stron. ${ }^{27}$ Jednak choć zamawiający nie może żądać, by dany produkt lub usługa legitymowały się daną ekoetykietą, może jak najbardziej opisać przedmiot zamówienia, wskazując pewne jego cechy, których ekoetykieta jest potwierdzeniem. Żądanie posiadania danej ekoetykiety byłoby naruszeniem zasady uczciwej konkurencji i równego traktowania (zwłaszcza w sytuacji, gdyby daną ekoetykietą legitymował się tylko jeden lub paru wykonawców). Ekoetykieta nie może być bowiem w zamówieniach publicznych jedynym sposobem potwierdzenia spełniania środowiskowych wymogów.

\section{Warunki udziału w postępowaniu a zrównoważony rozwój}

Zamawiający ma także dodatkowe możliwości uwzględniania zasad zrównoważonego rozwoju $\mathrm{w}$ zakresie kształtowania warunków udziału w postępowaniu o udzielenie zamówienia publicznego na dwóch poziomach, w zakresie kształtowania wiedzy i doświadczenia wykonawcy, jak również w zakresie dysponowania odpowiednim potencjałem technicznym. W ustawie p.z.p. wyraźnie podkreślono, iż podmiot, który dopuścił się przestępstwa przeciwko środowisku ${ }^{28}$ nie może ubiegać się o udzielenie zamówienia publicznego, co należy uznać za pozytywny przejaw

Cykl życia produktu - należy przez to rozumieć wszelkie możliwe kolejne fazy istnienia danego produktu, to jest: badanie, rozwój, projektowanie przemysłowe, produkcję, naprawę, modernizację, zmianę, utrzymanie, logistykę, szkolenie, testowanie, wycofanie i usuwanie.

26 Karta produktu jest podsumowaniem kryteriów GPP opracowanych dla grupy produktów, nie ma mocy wiążącej, jedynie stanowi pomoc zamawiającym w tworzeniu opisów przedmiotów zamówienia z uwzględnieniem kryteriów środowiskowych.

27 Opinia Komisji Ochrony Środowiska Naturalnego, Zdrowia Publicznego i Bezpieczeństwa Żywności dla Komisj Rynku Wewnętrznego i Ochrony Konsumentów w sprawie wniosku dotyczącego dyrektywy Parlamentu Europejskiego i Rady w sprawie zamówień publicznych, (COM(2011)0896 - C7 0006/2012 - 2011/0438(COD)), s. 14. 
działania ustawodawcy oraz za element wspierania zrównoważonego rozwoju. Jednocześnie zamawiający ma prawo do wprowadzenia ograniczeń w zakresie ubiegania się o udzielanie zamówienia publicznego w postaci posiadania zaświadczeń dotyczących wnoszenia opłat środowiskowych, posiadania stosownych zezwoleń środowiskowych, wyposażenia służącego ochronie środowiska czy stosowania systemu zarządzania środowiskowego (EMAS lub ISO14001). Oznacza to, że niespełnienie wymagań prawnych $\mathrm{w}$ zakresie ochrony środowiska oraz brak propozycji działań przyjaznych środowisku może wyeliminować oferenta z postępowania. Wyjątkową regulację, bo pozwalającą na ograniczenie kręgu wykonawców niezależnie od przedmiotu zamówienia, wprowadza art. 22 ust. 2., który może stanowić także element wpływania na zrównoważony rozwój społeczeństwa w zakresie zrównoważonego rozwoju społecznego. Na gruncie tego rozwiązania możliwe jest promowanie udziału w zamówieniach publicznych przedsiębiorstw, które zatrudniają osoby niepełnosprawne. Zamawiający może więc zastrzec, że zamówienie będzie dostępne jedynie dla takich wykonawców, u których ponad 50\% zatrudnionych pracowników stanowią osoby niepełnosprawne w rozumieniu przepisów o rehabilitacji zawodowej i społecznej oraz zatrudnianiu osób niepełnosprawnych lub właściwych przepisów państw członkowskich UE lub EOG. Warunkiem ograniczenia kręgu wykonawców tylko do takich podmiotów jest odpowiednie upublicznienie warunku w ogłoszeniu o zamówieniu.

Zamawiający pomimo posiadania dużej swobody w zakresie kształtowania wymogów udziału w postępowaniu o udzielenie zamówienia publicznego, jak również w uwzględnianiu zasad zrównoważonego rozwoju musi pamiętać, iż określenie przez niego warunków udziału w postępowaniu musi zapewnić udzielenie zamówienia publicznego wykonawcy gwarantującemu należyte wykonanie zamówienia. ${ }^{29}$ $\mathrm{W}$ tym celu zamawiający może posłużyć się warunkami wskazanymi w art. 22 ust. 1 ustawy p.z.p., jednocześnie należy zwrócić uwagę, iż zgodnie z postanowieniem art. 22 ust. 2 ustawy p.z.p. zamawiający nie może określać warunków udziału w postępowaniu o udzielenie zamówienia w sposób, który mógłby utrudniać uczciwą konkurencję. ${ }^{30} \mathrm{Z}$ możliwości, którą daje art. 22 warto korzystać szczególnie w przypadku udzielania zamówień na tych terenach, które są ekologicznie zagrożone. Takie działanie byłoby też zgodne z ustaloną przez prawo ochrony środowiska funkcją konserwatorską, mającą na celu zachować środowisko w stanie możliwie niezmienionym, uwzględniając oczywiście jego niezbędną eksploatację. Środowiskowe kryteria udziału w postępowaniu mogą dotyczyć właściwego potencjału technicznego wykonawcy lub posiadanego przez wykonawcę doświadczenia, który wykaże, iż realizacja przedsięwzięcia zapewni realizację celów zamawiającego oraz dodatkowo będzie pozytywnie oddziaływała na środowisko, a w konsekwencji przyczyni się 
do zapewnienia realizacji zasad zrównoważonego rozwoju. Rzeczywista realizacja zasad zrównoważonego rozwoju zależy od świadomości zamawiających i jego roli w kształtowaniu standardów wymagań wobec wykonawców.

\section{Podsumowanie}

„Zielone” zamówienia publiczne i zrównoważony rozwój są zagadnieniami blisko ze sobą powiązanymi, jednakże należy podkreślić, iż zrównoważony rozwój jest szerszą koncepcją, ma charakter bardziej ogólny. Polityka „zielonych” zamówień publicznych jest jedynie uprawnieniem zamawiającego, który może wykorzystać ją $\mathrm{w}$ ramach procedury realizacji postępowania o udzielenie zamówienia publicznego. Nie należy jednak rozdzielać tych dwóch kwestii, bowiem jak wskazano powyżej zamówienia publiczne mogą być przykładem uwzględniania przez zamawiających zasad zrównoważonego rozwoju. Pomimo że usługi, dostawy bądź roboty budowlane mają zaspokajać potrzeby zamawiających, mogą one stanowić efektywny sposób wspierania zrównoważonego rozwoju. Podmioty objęte obowiązkiem stosowania mogą wprowadzając wymagania w zakresie posiadania procedur ochrony środowiska bądź metod produkcji danego wyrobu w rzeczywistości realizować idee zrównoważonego rozwoju. Elementy kryteriów środowiskowych nie mogą jednak wprowadzać ograniczeń w zakresie dostępu do ubiegania się o zamówienia publiczne ani również blokować procedur realizacji zamówień publicznych. W związku z powyższym uwzględnienie elementów idei zrównoważonego rozwoju w zamówieniach publicznych powinno być świadome i konsekwentne, bowiem jednorazowe działania w zakresie stosowania kryteriów środowiskowych nie przyniosą zakładanego efektu. Zrównoważone zamówienia publiczne oznaczają świadome podejmowanie decyzji dotyczących zakupu, wyboru produktów i usług przyjaznych dla środowiska oraz uwzględnianie społecznych i ekonomicznych konsekwencji naszego wyboru. 


\section{PRINCIPLES OF SUSTAINABLE DEVELOPMENT POLICY USED IN PUBLIC PROCUREMENT}

This article presents the legal possibilities of integrating sustainable development policy with procedures for the award of a public contracts. Procurement procedure in which the contracting authority makes use of environmental criteria are referred to as green public procurement. Environmental criteria can attach to contractors and may also be a criterion for the evaluation of tenders. The policy of sustainable development can provide a positive change in the quality of goods ordered by public entities. Conscious use of GPP is one of the powers of public authority which enable it to create a public procurement market.

Keywords: sustainable development, public procurement, green public procurement, environmental standard, non-price standard, public authorities 